\title{
Sedative antidepressants and insomnia
}

\section{Antidepressivos sedativos e insônia}

\author{
Walter André dos Santos Moraes, ${ }^{1}$ Patrick Rademaker Burke, ${ }^{1}$ Pablo Lorenzon Coutinho, ${ }^{1}$ Christian \\ Guilleminault, ${ }^{2}$ Aline Gomes Bittencourt, ${ }^{1}$ Sergio Tufik, ${ }^{1}$ Dalva Poyares ${ }^{1}$ \\ ${ }^{1}$ Psychobiology Department, Universidade Federal de São Paulo (UNIFESP), São Paulo, SP, Brazil \\ ${ }^{2}$ Human Sleep Research Center, Department of Psychiatry and Behavioral Science, School of Medicine, Stanford University, Palo Alto, CA, USA
}

\begin{abstract}
Objective: The present review addresses the relationship between sleep and depression and how serotonergic transmission is implicated in both conditions. Method: Literature searches were performed in the PubMed and MedLine databases up to March 2010. The terms searched were "insomnia", "depression", "sedative antidepressants" and "serotonin". In order to pinpoint the sedative antidepressants most used to treat insomnia, 34 ISI articles, mainly reviews and placebo-controlled clinical trials, were selected from 317 articles found in our primary search. Results: Sleep problems may appear months before the diagnosis of clinical depression and persist after the resolution of depression. Treatment of insomnia symptoms may improve this comorbid disease. Some antidepressant drugs can also result in insomnia or daytime sleepiness. Serotonin (5-HT) demonstrates a complex pattern with respect to sleep and wakefulness that is related to the array of 5-HT receptor subtypes involved in different physiological functions. It is now believed that $5 \mathrm{HT}_{2}$ receptor stimulation is subjacent to insomnia and changes in sleep organization related to the use of some antidepressants. Conclusion: Some drugs commonly prescribed for the treatment of depression may worsen insomnia and impair full recovery from depression. $5-\mathrm{HT}_{2}$ receptor antagonists are promising drugs for treatment strategies since they can improve comorbid insomnia and depression.
\end{abstract}

Descriptors: Neurochemistry; Antidepressive agents; Sleep; Depressive disorder; Psychopharmacology

\section{Introduction}

Sleep disorders have been reported as symptoms seen in many depressed patients. ${ }^{1}$ Insomnia may occur in $60-80 \%$ of patients with major depressive disorder and hypersomnia in approximately 15-20\%. . Depressive symptoms are important risk factors for insomnia, and depression is considered an important comorbid condition in patients with chronic insomnia of any etiology. ${ }^{3}$ Insomnia and sleepiness may also occur as side effects of some antidepressant drugs. ${ }^{4}$

Different models have been proposed to explain changes in sleep patterns associated with depression. Process $S$, for instance,

\section{Resumo}

Objetivo: Esta atualização aborda a relação entre sono e depressão e como a transmissão serotoninérgica está envolvida em ambas condiçôes. Método: Foi realizada uma busca na literatura no PubMed e MedLine até março de 2010 com os termos "insônia", "depressâo", "antidepressivos sedativos" e "serotonina". A fim de contemplar os antidepressivos sedativos mais utilizados no tratamento da insônia, 34 artigos ISI, principalmente revisöes e estudos clinicos placebo-controlados, foram selecionados entre 317 artigos encontrados na busca inicial. Resultados: Alteraçōes de sono podem aparecer meses antes do diagnóstico clínico de depressão e persistir após a resolução da depressão. $O$ tratamento dos sintomas de insônia pode melhorar essa doença associada. Alguns antidepressivos também podem levar à insônia ou sonolência diurna. A serotonina (5-HT) demonstra um padräo complexo no que diz respeito ao sono e vigilia, o que está relacionado com a variedade de subtipos do receptor 5-HT envolvidos em diferentes funçōes fisiológicas. Acredita-se, atualmente, que a estimulação do receptor $5-\mathrm{HT}_{2}$ esteja envolvida nas alteraçōes da organização do sono e insônia relacionada a alguns antidepressivos. Conclusáo: Alguns medicamentos normalmente prescritos para o tratamento de depressão podem piorar a insônia e dificultar a completa recuperação da depressão. Os antagonistas do receptor $5-\mathrm{HT}_{2}$ são drogas promissoras para o tratamento, pois podem melhorar a insônia e depressão associadas.

Descritores: Neuroquimica; Antidepressivos; Sono; Transtorno depressivo; Psicofarmacologia

refers to the quantitative need for sleep that builds up while a person is awake and declines during sleep, and is dependent on how long a person is awake and on how active they are while awake. The deficiency theory states that Process $S$ in depressive patients is deficient in the waking state, which is reflected in reduced delta activity. Some authors have described how the delta ratio (delta sleep duration from the first to the second rapid eye movement - REM - period) is reduced in depressive patients. ${ }^{5-7}$ Another model is based on experimental evidence on the reciprocal interaction between cholinergic REM-on and aminergic REMoff neurons. ${ }^{5,6}$ REM-suppressive antidepressant therapy supports

\section{Correspondence}

Patrick Rademaker Burke

Psychobiology Department, Universidade Federal de São Paulo

R. Napoleão de Barros, 925

04024-002 São Paulo, SP, Brasil

Phone: (+55 11) 2149-0155

Email: doctorburke@hotmail.com 
this model. Cholinergic/aminergic interaction is subject to both ultradian and circadian cycles. The internal coincidence model supposes that there is a strong circadian oscillator controlling REM sleep and a weak oscillator controlling the wake-sleep cycle. ${ }^{5}$ In depressive patients the strong oscillator is in the advanced phase, causing them to sleep late in relation to the biological clock. ${ }^{5}$ The activation model $^{5}$ suggests that depressive patients present altered regulation of cortical activation, so that they tend to remain in a hyper-activated state during wakefulness. If, on one hand, brain imaging of glucose metabolism supports the hyperactivation theory, on the other hand, clinical evidence shows that hypo-activation symptoms are frequent and that unidimensional models are inadequate. ${ }^{5}$

\section{Method}

This is an updated report which focuses on the relationship between sleep, insomnia, 5HT and depression, with particular attention to sedative antidepressants in the context of insomnia. Other effects of antidepressants, with the exception of sedation, are beyond the scope of this report. For concision, we included the most commonly prescribed compounds of this class, which included: trazodone, mirtazapine, agomelatine and doxepine Literature searches were performed in the PubMed and MedLine databases up to March 2010. The terms searched were "insomnia", "depression", "sedative antidepressants" and "serotonin". We started with 317 references and have given priority to reviews (15), randomized placebo-controlled studies and other controlled studies (11), but also included update articles (2), cohort and epidemiological studies (4), an open label study (1) and experimental data in humans and animals (3). Case reports and articles assessing other sedative-hypnotic substances were excluded. A total of 34 references were included.

Among reviews and controlled studies we have included about three articles for each of the mentioned sedative antidepressants.

\section{The relationship between sleep and depression}

Depressive symptoms are the greatest and most consistent risk factors for insomnia, which is often the presenting symptom in the depressed patient seeking help. 5 Sleep problems may appear months before the diagnosis of clinical depression and persist after its resolution; treatment of insomnia symptoms may improve this comorbid disease. In fact, patients with chronic insomnia, lasting for many years, present significant scores in depression scales even when DSM-IV criteria for major depression are not fulfilled. ${ }^{8}$ Data indicate that insomnia can precede episodes of depression by 5 weeks. ${ }^{9}$ Treating insomnia may prevent or shorten the period of depression. Symptoms related to insomnia may also be related to depression.

Sleep duration is believed to be particularly important in predicting manic and depressive symptoms. Sleep deprivation was associated with temporary remission of depressive symptoms. Insomnia was classified in a study as onset, maintenance, mixed (no onset or maintenance disturbance) and combined (both onset and maintenance disturbance). ${ }^{10}$ Patients with the latter type had higher Beck Depression Inventory scores,${ }^{10}$ indicating that patients with persistent insomnia were 1.8-3.5 times more likely to remain depressed, compared with patients with no insomnia. ${ }^{10}$ This suggests that in addition to being a risk factor for depressive episodes, persistent insomnia perpetuates the illness in some elderly patients. ${ }^{11}$ Consequently, managing insomnia may enhance the treatment outcome of this comorbid disease. ${ }^{8}$ There is a dearth of clinical trials examining the effectiveness of hypnotics in the treatment of depression associated with insomnia. Some studies show that relief of sleep disturbance is often determinant of compliance with antidepressant treatment.

To date there have been few studies evaluating the efficacy of antidepressant drugs in primary insomnia. ${ }^{1}$ A randomized trial compared the efficacy of trazodone therapy to zolpidem therapy and placebo for patients with primary insomnia. ${ }^{12}$ Compared to zolpidem, trazodone was less effective in improving sleep disturbances in those patients. ${ }^{12}$ Despite the widespread use of trazodone for insomnia, there are limited data available, most of them on insomnia associated with depression. ${ }^{12}$ More studies are needed on the effect and long-term safety of trazodone in primary insomnia and in the elderly, among whom its use is frequent. A randomized crossover study, using polysomnography and patient reporting, evaluated doxepin therapy for adults with primary insomnia, ${ }^{1,13}$ and has shown its efficacy in improving sleep. ${ }^{13}$ Trimipramine and paroxetine were also analyzed, but results were not promising. ${ }^{1}$ Thus, there is no evidence that antidepressants are superior to the new nonbenzodiazepine hypnotics to treat primary insomnia.

\section{Selective serotonin reuptake inhibitors and their impact on sleep}

The most common sleep disturbances in depressed patients, as documented in visually-scored polysomnograms, include:

1) Altered duration and sustenance of sleep. Total sleep time is reduced, due to an increase in sleep latency and wake time after sleep onset (WASO), and early morning awakening. However, $15-20 \%$ present hypersomnia. ${ }^{5,14}$ Depressive individuals frequently show sleep-stage changes and a higher arousability. Sleep quality is reduced due to sleep fragmentation.

2) Reduced REM sleep latency, increment of first REM period, increased REM sleep in the first third of the night and reduced REM sleep in the latter. Increased REM density during the first third of the night. ${ }^{5,14}$

3) Reduced slow-wave sleep (SWS) duration and proportion. Spectral analysis studies show reduced slow-wave activity during non-REM sleep, especially in the first period. . $^{51}$

The most persistent polysomnographic alterations in depressed patients are a reduction in the amount of slow-wave sleep and reduced REM-sleep latency. ${ }^{15}$

Research suggests that the same neurotransmitter systems that regulate mood, motivation and energy can be abnormally regulated in depression and contribute to sleep disturbance. ${ }^{1,4}$ Some neurotransmitter systems have been implicated in the maintenance of wakefulness, the initiation and maintenance of 
sleep and the transitions, within sleep, from one state to another. ${ }^{1}$ The currently approved antidepressant drugs exert effects on one or several of these neurotransmitter systems, so it is not surprising that the antidepressant drugs produce diverse effects on sleep and wakefulness. ${ }^{1,16-18}$ Tricyclic antidepressants block presynaptic reuptake of norepinephrine and 5-HT (serotonin). ${ }^{1,17,18}$ Some are more selective for norepinephrine (desipramine, protriptyline) increasing awakenings and reducing total sleep time. ${ }^{1,17-19}$ Others preferentially act upon 5-HT (clomipramine, amitriptyline, doxepin) inducing sleep and daytime somnolence. ${ }^{1,16-18}$ Tricyclic antidepressants have other effects on neurotransmitter systems, including blockade of histamine $\mathrm{H}_{1}$, alpha ${ }_{1}$ andrenergic and muscarinic cholinergic receptors, and may lead to daytime sleepiness. ${ }^{1,17-19}$ Tricyclics also produce potent REM sleep suppression. Inhibitors of the enzyme monoamine oxidase enhance monoamine neurotransmission by increasing presynaptic concentrations of norepinephrin, dopamine and 5-HT. ${ }^{1,16-19}$ This catecholaminergic stimulation may disrupt sleep continuity. ${ }^{1}$ By increasing monoaminergic transmission, REM sleep muscle tonus regulation may be disturbed in rare cases, inducing episodes of REM sleep behavior disorder. ${ }^{20}$

Serotonin demonstrates a more complex pattern with respect to sleep and wakefulness that is related to the array of 5-HT receptor subtypes involved in different physiological functions. Serotonergic neurons play a vital role in the modulation of the onset and maintenance of sleep, and sleep disturbance in depression is linked to alterations of serotonergic pathways. ${ }^{1,4}$ Depressed individuals treated with serotonin reuptake inhibitors (SSRIs) often complain of persistent sleep disturbances such as insomnia and daytime somnolence. ${ }^{4}$ Corroborating the clinical data, polysomnography often demonstrates that SSRI therapy is associated with greater fragmentation of sleep, suppression of REM sleep, prolonged sleep latency and reduced total sleep time. ${ }^{1}$ Insomnia during the use of fluoxetine represented one of the most common side effects. ${ }^{1}$ Paradoxically, daytime somnolence has also frequently been reported. ${ }^{1,18}$ Fluoxetine has been shown to reduce REM sleep. ${ }^{1,17,18}$ Polysomnographic studies showed that paroxetine, sertraline, citalopram and escitalopram presented similar adverse effects on sleep although these were less pronounced. ${ }^{1,17,18}$ Disruption of sleep continuity appears to be a dose-dependent effect of the SSRIs. ${ }^{1}$ They cause insomnia in $10-20 \%$ of depressed patients due to the suppression of REM sleep. ${ }^{1,17,18}$

Pharmacological studies have implicated serotonin as a promoter of sleep. In experimental conditions, the blocking of 5-HT synthesis caused long-lasting insomnia. ${ }^{21}$ However, stimulation of the dorsal raphe nucleus of cats elicits arousal. ${ }^{21}$ Stimulation during REM sleep suppresses ponto-geniculooccipital waves associated with REM sleep. ${ }^{21}$ 5-HT receptors have a complex role in promoting and regulating wakefulness and sleep. ${ }^{22} 5-\mathrm{HT}_{2 \mathrm{~A}}$ and 5- $\mathrm{HT}_{2 \mathrm{~B}}$ receptors seem to have opposite roles. $5-\mathrm{HT}_{2 \mathrm{~B}}$ stimulation promotes sleep. $5-\mathrm{HT}_{1 \mathrm{~A}}$ and $5-\mathrm{HT}_{1 \mathrm{~B}}$ have an inhibitory action on REM sleep.
Some antidepressants, especially $5-\mathrm{HT}_{2}$ antagonists, have beneficial effects by increasing SWS duration, sparing REM sleep. ${ }^{1,17,18}$ The precursors of 5-HT biosynthesis, L-tryptophan and 5-hydrosytryptophan, have promoted the onset of sleep ${ }^{1,21}$ Depletion of 5-HT by reserpine produces states of profound insomnia. ${ }^{1,21}$ Among 5-HT receptors subtypes, 5- $\mathrm{HT}_{1}$ and 5- $\mathrm{HT}_{2}$ are closely related to alertness. $5-\mathrm{HT}_{2}$ receptors (A, B and C subtypes) activate phospholipase $\mathrm{C}$, and can be considered excitatory. ${ }^{21} 5-\mathrm{HT}_{1 \mathrm{~A}}$ receptor agonists decrease REM sleep duration and sleep fragmentation. ${ }^{17,22,23} 5-\mathrm{HT}_{2 \mathrm{~A}}$ receptors are found in the cortex and basal ganglia, mediate certain behavioral syndromes and are implicated in the pathophysiology of psychiatric disorders associated with sleep disturbances such as depression and psychosis. ${ }^{21} \mathrm{It}$ is believed that $5 \mathrm{HT}_{2}$ receptor stimulation is subjacent to insomnia and to sleep architecture alterations related to SSRIs. ${ }^{1}$ For this reason, $5 \mathrm{HT}_{2}$ blockers, like trazodone, improve insomnia and ameliorate sleep structure. $5 \mathrm{HT}_{2}$-blocker antidepressants are a good option to treat insomniac depressive patients. ${ }^{17}$ Polysomnography in patients treated with trazodone showed increased slow-wave sleep (SWS) during the first half of the night by intensifying the mechanism that generates it. ${ }^{24}$ Long-term treatment showed increased sleep duration in stage 2, reduced sleep latency, increased delta sleep, and reduced REM latency. ${ }^{1,25}$

\section{Treatment of comorbid insomnia and depression}

Successful treatment of patients with comorbid insomnia and depression requires attention to both conditions. ${ }^{26}$ Depressed patients with sleep disturbances have a significantly worse prognosis in relation to remission rates and the likelihood of complete and sustained recovery. ${ }^{26}$ Continued insomnia following antidepressant therapy is related to risk of relapse. ${ }^{26}$ In a longitudinal study, two-thirds of patients with persistent insomnia at the end of treatment with antidepressants and psychotherapy relapsed within one year after switching to a placebo. ${ }^{27}$ On the other hand, $90 \%$ of patients with good sleep patterns remained well during the first year after discontinuing antidepressants. ${ }^{27}$ There is some evidence that insomnia may be the first prodromal symptom in previously remitted patients. ${ }^{27}$ When sleep disturbances become associated with distress and impairment of functioning in significant domains, and criteria for the diagnosis of insomnia are met, then insomnia is no longer a symptom of depression but a comorbid disorder that may impair the response to antidepressants. ${ }^{26}$ The majority of currently available antidepressants and hypnotic medications do not improve SWS, a target for improving depression and insomnia. ${ }^{1}$ Some antidepressants such as trazodone and nefazodone are effective in restructuring sleep architecture and are potentially options for simultaneously reducing depression and insomnia. ${ }^{1,4}$ Trazodone has shown to exert inhibitory actions on $5-\mathrm{HT}_{1 \mathrm{~A}}, 5-\mathrm{HT}_{1 \mathrm{C}}$ and 5- $\mathrm{HT}_{2}$ receptors, which may contribute to its sleep-promoting properties. It also produces inhibitory effects at the presynaptic 5-HT reuptake site. The combination of weak inhibition of 5-HT 
reuptake and blockade of 5- $\mathrm{HT}_{2}$ receptors explains the fact that trazodone enhances SWS and causes minimal, if any, suppression of REM sleep. Trazodone also inhibits alpha-1 adrenoreceptors and, slightly, histamine $\mathrm{H}_{1}$ receptors, contributing to promotion of sleep. ${ }^{1,24}$ Nefazodone exerts weak 5-HT presynaptic reuptake inhibition together with blockade of $5-\mathrm{HT}_{2}$ receptors, preserving sleep architecture and REM sleep. Bupropion is associated with insomnia in some cases. ${ }^{1}$ In contrast with most antidepressants, bupropion increases REM sleep. Bupropion blocks presynaptic reuptake of dopamine and norepinephrin, ${ }^{1}$ although it modestly enhances catecholamine neurotransmission. Mirtazapine demonstrates potent sleep-promoting effects by inhibiting the presynaptic alpha-2 autoreceptors, which increases norepinephrin and 5-HT, blocking both the 5- $\mathrm{HT}_{2}$ and $5-\mathrm{HT}_{3}$ postsynaptic receptors, and blocking histamine- $\mathrm{H} 1$ receptors.

Agents that selectively target $5-\mathrm{HT}_{2}$ hold great promise for the treatment of the comorbid conditions. Studies have shown that Ritanserin, a potent 5- $\mathrm{HT}_{2}$ antagonist, significantly improved SWS and sleep quality in major depression. Another study on ritanserin in narcolepsy showed improved sleep quality and reduced daytime sleepiness. ${ }^{28}$ Other selective drugs are under development: eplivanserin and volinanserin. Some drugs combine blockade of 5- $\mathrm{HT}_{2}$ receptors with other pharmacological targets: agomelatin, a melatonin receptor agonist and 5- $\mathrm{HT}_{2}$ antagonist has effective antidepressant and hypnotic activity. ${ }^{29-31}$

\section{Conclusion}

Present knowledge suggests that some neurotransmitter systems are simultaneously implicated in mood disorders and sleep disturbances. ${ }^{1,4}$ Deeper non-REM sleep (SWS) is very important for maintaining homeostasis ${ }^{1,32}$ and is related to restorative sleep and well-being. ${ }^{1,32}$ Some drugs prescribed for the treatment of depression may worsen insomnia and impair full recovery from depression. ${ }^{1,4}$ Thus, new drugs have been developed that may be able to manage depression and insomnia symptoms simultaneously. ${ }^{1,4,18,33} 5-\mathrm{HT}_{2}$ receptor antagonists are promising drugs for treatment strategies since they can improve comorbid insomnia and depression. ${ }^{1,27,33}$ Future research is needed to address the simultaneous treatment of insomnia and mood disorders to foster a better treatment outcome and to address the long-term safety and efficacy of $5 \mathrm{HT}_{2}$ antagonists in the treatment of primary insomnia.

In addition, future studies to uncover the neurobiology that is thought to underlie insomnia and depression are needed. ${ }^{34}$

\section{Disclosures}

\begin{tabular}{|c|c|c|c|c|c|c|c|}
\hline $\begin{array}{l}\text { Writing group } \\
\text { member }\end{array}$ & Employment & $\begin{array}{l}\text { Research } \\
\text { grant }^{1}\end{array}$ & $\begin{array}{l}\text { Other research grant or } \\
\text { medical continuous } \\
\text { education }{ }^{2}\end{array}$ & $\begin{array}{l}\text { Speaker's } \\
\text { honoraria }\end{array}$ & $\begin{array}{l}\text { Ownership } \\
\text { interest }\end{array}$ & $\begin{array}{l}\text { Consultant/ } \\
\text { Advisory board }\end{array}$ & Other ${ }^{3}$ \\
\hline $\begin{array}{l}\text { Walter André } \\
\text { dos Santos } \\
\text { Moraes }\end{array}$ & UNIFESP & - & - & - & - & - & - \\
\hline $\begin{array}{l}\text { Patrick } \\
\text { Rademaker } \\
\text { Burke }\end{array}$ & UNIFESP & - & - & - & - & - & - \\
\hline $\begin{array}{l}\text { Pablo Lorenzon } \\
\text { Coutinho }\end{array}$ & UNIFESP & - & - & - & - & - & - \\
\hline $\begin{array}{l}\text { Christian } \\
\text { Guilleminault }\end{array}$ & $\begin{array}{l}\text { Stanford } \\
\text { University }\end{array}$ & - & - & - & - & - & - \\
\hline $\begin{array}{l}\text { Aline Gomes } \\
\text { Bittencourt }\end{array}$ & UNIFESP & - & - & - & - & - & - \\
\hline Dalva Poyares & UNIFESP & - & - & - & - & - & - \\
\hline \multicolumn{8}{|c|}{$\begin{array}{l}\text { * Modest } \\
\text { ** Significant } \\
\text { *** Significant: Amounts given to the author's institution or to a colleague for research in which the author has participation, not directly to the } \\
\text { author. }\end{array}$} \\
\hline
\end{tabular}

References

1. DeMartinis NA, Winokur A. Effects of psychiatric medications on sleep and sleep disorders. CNS Neurol Disord Drug Targets. 2007;6(1):17-29.

2. Winokur A, Gary KA, Rodner S, Rae-Red C, Fernando AT, Szuba MP. Depression, sleep physiology, and antidepressant drugs. Depress Anxiety. 2001;14(1):19-28.

3. Buysse DJ, Angst J, Gamma A, Ajdacic V, Eich D, Rössler W. Prevalence, course, and comorbidity of insomnia and depression in young adults. Sleep. 2008;31(4):473-80
4. Antai-Otong D. Antidepressant-induced insomnia: treatment options. Perspect Psychiatr Care. 2004;40(1):29-33.

5. Thase ME. Depression, sleep, and antidepressants. J Clin Psychiatry. 1998;59(4):55-65.

6. Viot-Blanc V. Biological models of depression: effect of antidepressants on sleep. Encephale. 1995;21(7):35-40.

7. Borbély AA. The S-deficiency hypothesis of depression and the two-process model of sleep regulation. Pharmacopsychiatry. 1987;20(1):23-9.

8. Turek FW. Insomnia and depression: if it looks and walks like a duck. Sleep. 2005;28(11):1362-3. 
9. Pigeon W, Hegel M, MacKenzie T, Lyness JM, Sateia MJ, Perlis ML. Insomnia as a risk for increased morbidity in depressed elderly subjects treated for depression: the impact cohort. Sleep. 2005;28:A307.

10. Taylor DJ, Lichstein KL, Durrence HH, Reidel BW, Bush AJ. Epidemiology of insomnia, depression, and anxiety. Sleep. 2005;28(11):1457-64.

11. Pigeon WR, Hegel M, Unützer J, Fan MY, Sateia MJ, Lyness JM, Philips C, Perlis ML. Is insomnia a perpetuating factor for late-life depression in the IMPACT cohort? Sleep. 2008;31(4):481-8.

12. Walsh JK, Erman M, Erwin CW, Jamieson A, Mahowald M, Regestein Q1. Subjective hypnotic efficacy of trazodone and zolpidem in DSM-III-R primary insomnia. Hum Psychopharmacol. 1998;13:191-8.

13. Roth T, Rogowski R, Hull S, Schwartz H, Koshorek G, Corser B, Seiden D, Lankford A. Efficacy and safety of doxepin $1 \mathrm{mg}, 3 \mathrm{mg}$, and $6 \mathrm{mg}$ in adults with primary insomnia. Sleep. 2007;30(11):1555-61.

14. Landolt HP, Gillin JC. Similar sleep EEG topography in middle-aged depressed patients and healthy controls. Sleep. 2005;28(2):239-47.

15. Quera Salva MA, Vanier B, Laredo J, Hartley S, Chapotot F, Moulin C, Lofaso F, Guilleminault C. Major depressive disorder, sleep EEG and agomelatine: an open-label study. Int J Neuropsychopharmacol. 2007;10(5):691-6.

16. Holshoe JM. Antidepressants and sleep: a review. Perspect Psychiatr Care. 2009;45(3):191-7.

17. Popa D, El Yacoubi M, Vaugeois JM, Hamon M, Adrien J. Homeostatic regulation of sleep in a genetic model of depression in the mouse: effects of muscarinic and 5-HT1A receptor activation. Neuropsychopharmacology. 2006;31(8):1637-46.

18. Thase ME. Antidepressant treatment of the depressed patient with insomnia. J Clin Psychiatry. 1999;60(17):28-31.

19. Wiegand MH. Antidepressants for the treatment of insomnia: a suitable approach? Drugs. 2008;68(17):2411-7.

20. Gagnon JF, Rompré S, Montplaisir JY. Update on the pharmacology of REM sleep behavior disorder. Neurology. 2006;67(5):742-7.

21. Stenberg D. Neuroanatomy and neurochemistry of sleep. Cell Mol Life Sci. 2007;64(10):1187-204.

22. Darnall RA, Harris MB, Gill WH, Hoffman JM, Brown JW, Niblock MM. Inhibition of serotonergic neurons in the nucleus paragigantocellularis lateralis fragments sleep and decreases rapid eye movement sleep in the piglet: implications for sudden infant death syndrome. J Neurosci. 2005;25(36):8322-32.

23. Teegarden BR, Al Shamma H, Xiong Y. $5-\mathrm{HT}_{2 \mathrm{~A}}$ inverse-agonists for the treatment of insomnia. Curr Top Med Chem. 2008;8(11):969-76.

24. Yamadera H, Nakamura S, Suzuki H, Endo S. Effects of trazodone hydrochloride and imipramine on polysomnography in healthy subjects. Psychiatry Clin Neurosci. 1998;52(4):439-43.

25. Haria M, Fitton A, McTavish D. Trazodone. A review of its pharmacology, therapeutic use in depression and therapeutic potential in other disorders. Drugs Aging. 1994;4(4):331-55.

26. Manber R, Edinger JD, Gress JL, San Pedro-Salcedo MG, Kuo TF, Kalista T. Cognitive behavioral therapy for insomnia enhances depression outcome in patients with comorbid major depressive disorder and insomnia. Sleep. 2008;31(4):489-95.

27. Reynolds CF 3rd, Frank E, Houck PR, Mazumdar S, Dew MA, Cornes C, Buysse DJ,Begley A, Kupfer DJ. Which elderly patients with remitted depression remain well with continued interpersonal psychotherapy after discontinuation of antidepressant medication? Am J Psychiatry. 1997;154(7):958-62.

28. Mayer G. Ritanserin improves sleep quality in narcolepsy. Pharmacopsychiatry. 2003;36(4):150-5.

29. Lemoine P, Guilleminault C, Alvarez E. Improvement in subjective sleep in major depressive disorder with a novel antidepressant, agomelatine: randomized, double-blind comparison with venlafaxine. J Clin Psychiatry. 2007;68(11):1723-32.

30. Pandi-Perumal SR, Trakht I, Srinivasan V, Spence DW, Poeggeler B, Hardeland $\mathrm{R}$, Cardinali DP. The effect of melatonergic and non-melatonergic antidepressants on sleep: weighing the alternatives. World J Biol Psychiatry. 2009;10(4 Pt 2):342-54.

31. Mendlewicz J.Disruption of the circadian timing systems: molecular mechanisms in mood disorders. CNS Drugs. 2009;23 Suppl2:15-26.

32. Tasali E, Leproult R, Ehrmann DA, Van Cauter E. Slow-wave sleep and the risk of type 2 diabetes in humans. Proc Natl Acad Sci USA. 2008;105(3):1044-9.
33. Staner L, Kempenaers C, Simonnet MP, Fransolet L, Mendlewicz J. 5-HT2 receptor antagonism and slow-wave sleep in major depression. Acta Psychiatr Scand. 1992;86(2):133-7.

34.Benca RM, Peterson MJ. Insomnia and depression. Sleep Med. 2008;9(1)S3-9. 